\title{
Impacts of marine biogeographic boundaries on phylogeographic patterns of three South African estuarine crustaceans
}

\author{
Peter R. Teske ${ }^{1,2, *}$, Christopher D. McQuaid ${ }^{2}$, P. William Froneman ${ }^{2}$, Nigel P. Barker $^{1}$ \\ ${ }^{1}$ Molecular Ecology and Systematics Group, Botany Department, Rhodes University, 6140 Grahamstown, South Africa \\ ${ }^{2}$ Department of Zoology and Entomology, Rhodes University, 6140 Grahamstown, South Africa
}

\begin{abstract}
The South African coastline comprises 3 main biogeographic provinces: (1) the cooltemperate west coast, (2) the warm-temperate south coast, and (3) the subtropical east coast. The boundaries between these regions are defined by changes in species compositions and hydrological conditions. It is possible that these affect phylogeographic patterns of coastal organisms differently, depending on the species' ecologies and modes of dispersal. In the present study, genealogies of 3 estuarine crustaceans, each characterized by a different mode of passive dispersal and present in more than one biogeographic province, were reconstructed using mtDNA COI sequences, and the impacts of biogeographic boundaries on their phylogeographic patterns were compared. The species were (mode of dispersal in brackets): (1) the mudprawn Upogebia africana (planktonic larvae), (2) the isopod Exosphaeroma hylecoetes (adult rafting), and (3) the cumacean Iphinoe truncata (adult drifting). Two major mtDNA lineages with slightly overlapping distributions were identified in U. africana (the species with the highest dispersal potential). The other 2 species had $3 \mathrm{mtDNA}$ lineages each, which were characterized by strict geographic segregation. Phylogeographic breaks in $U$. africana and E. hylecoetes coincided with biogeographic boundaries, whereas the phylogeographic patterns identified in I. truncata may reflect persistent palaeogeographic patterns. Ecological factors and modes of dispersal are likely to have played a role in both cladogenesis of the different lineages and in the establishment of their present-day distribution patterns.
\end{abstract}

KEY WORDS: Mode of dispersal $\cdot$ Planktonic larvae $\cdot$ Rafting $\cdot$ Isolation by distance $\cdot$ mtDNA cytochrome oxidase I P Parapatry

\section{INTRODUCTION}

The South African coastline stretches from the mouth of the Gariep (Orange) River on the west coast to Kosi Bay on the east coast (Fig. 1) and can be divided into biogeographic provinces characterized by different species assemblages and hydrological conditions. The 3 main regions are the cool-temperate west coast, the warm-temperate south coast, and the subtropical east coast. The exact locations of the boundaries separating these provinces are not agreed upon, and various smaller-scale groupings and regions of overlap have been suggested (see Harrison 2002 for a review).
Reasons for the lack of consensus may include biases in sampling effort towards certain taxa and areas, use of historical distribution records, sampling at different ocean depths, incomplete coverage of the coastline and use of different criteria to delineate biogeographic regions and identify boundaries (Harrison 2002, Bolton et al. 2004, Sink et al. 2004). The majority of studies have focused on similarities in species composition of one particular group of organisms, e.g. ichthyoplankton (Beckley \& van Ballegooyen 1992), estuarine fish (Harrison 2002), intertidal invertebrates (Emanuel et al. 1992), and seaweeds (Bolton et al. 2004). As environmental conditions along the coast are likely to 


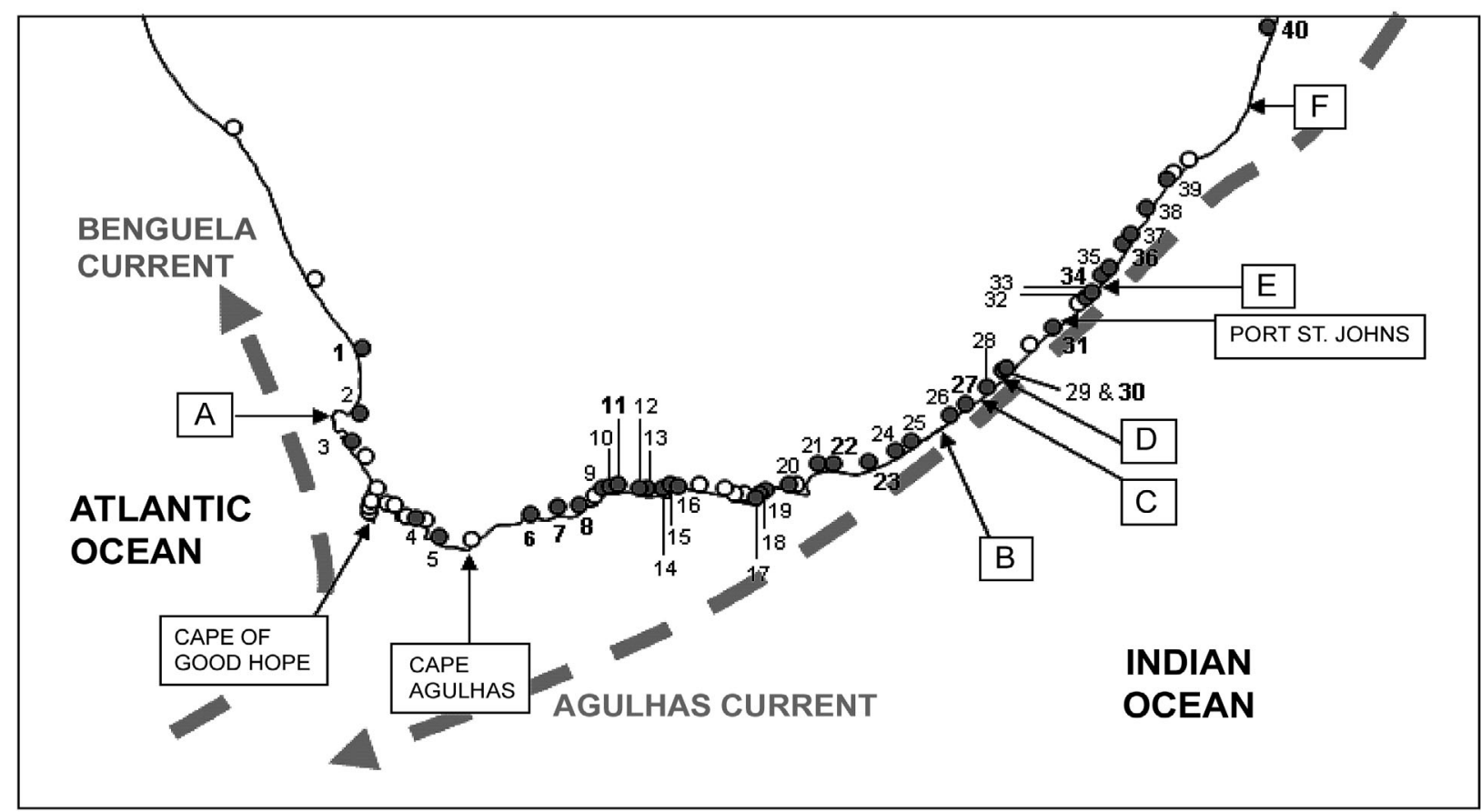

Fig. 1. Map of South Africa showing the estuaries sampled in this study, biogeographic boundaries suggested in the literature, and the 2 current systems dominating the region (the cool Benguela Current and the warm Agulhas Current). Estuaries in which at least 1 of the 3 species studied was found are represented by grey dots and a number. The names of these estuaries are shown in Table 1. Estuaries with numbers in boldface are mentioned in the text. Text boxes show the locations of boundaries between inshore biogeographic regions suggested in the literature; those discussed in the text are mentioned by name. Other boundaries that have been proposed are: A: Cape Columbine; B: East London; C: Kei River; D: Mbashe River; E: Port Edward; F: Cape Vidal. Estuarine systems represented by white dots were searched, but none of the 3 species studied were found. These include the Orange/Gariep, Groen*, Modder*, Riet, Houtbaai*, Schuster*, Krom*, Zandvlei, Rooiels*, Palmiet, Klein, Heuningnes, Hartenbos*, Storms, Tsitsikamma*, Klipdrif*, Slang*, Maitlands*, Mtonjane, Mtamvuna, Nyoni/Matigulu and Tugela*. *: systems with near-freshwater salinities during the sampling period, suggesting that they are not suitable to provide a long-term habitat for estuarine species

affect these taxa differently, attempts to define biogeographic barriers generally applicable to all coastal biota seem futile.

While it seems obvious that, for instance, rocky shore organisms experience very different environmental conditions from estuarine organisms occurring in close geographic proximity, the population structures and distribution ranges of even closely related taxa occurring in sympatry may differ considerably. For example, invertebrate species with a brief planktonic larval stage may be characterized by more genetic structure than sympatric species with larvae that remain in the plankton for longer (Todd et al. 1998, Riginos \& Victor 2001), and sessile marine species that lack dispersive larvae tend to be genetically more subdivided than closely related sympatric species with planktotrophic larvae (Kyle \& Boulding 2000, Collin 2001). These studies seem to indicate that there is a negative correlation between dispersal ability and genetic structure, but other recent studies have failed to find such a relationship. For example, some planktonic dispersers have surprisingly limited ranges because recruitment occurs locally (e.g. Jiang et al. 1995) and some species that were believed to have wide geographic ranges by virtue of their dispersal abilities actually comprised several regionally restricted sibling species (e.g. Knowlton 2000, Dawson \& Jacobs 2001). Despite such findings, it is nevertheless often assumed that the distributions of marine organisms are strongly influenced by their modes of dispersal (Avise et al. 1987).

Biotic changes along South Africa's coastline could to some extent reflect the inability of poorly-dispersing species to cross biogeographic barriers, which may have resulted in genetic divergence of regional units of such species due to low levels of gene-flow. Estuarine species seem particularly suitable to investigate this issue; even though the distribution of most species is not limited by high salinity (de Villiers et al. 1999, Teske \& Wooldridge 2003, 2004) and most have wide distribution ranges (e.g. Day 1974, Griffiths 1976, Steyn \& Lussi 1998), it is nonetheless likely that populations are isolated from each other by both geographical distance and the barrier represented by the ecologically and physiologically different marine habitat. 
Such species are thus likely to exhibit high levels of genetic structure along the South African coast, making them suitable model organisms to investigate the impacts of marine biogeographic boundaries on genetic structure.

To determine whether biogeographic patterns are reflected in phylogeographic patterns of estuarine species characterized by various modes of dispersal, we studied 3 passively-dispersing crustaceans endemic to southern Africa and present in more than one biogeographic province.

Upogebia africana (Ortmann, 1894) (mudprawn) is a thalassinid prawn associated with muddy sediments (Wooldridge \& Loubser 1996). Its distribution ranges from the Olifants Estuary on the west coast of South Africa to Morrumbene in Mozambique (Day 1974). Adults are sessile and unlikely to disperse over great distances, but larvae must complete development in the marine environment (Wooldridge 1994) and have a larval duration of up to $27 \mathrm{~d}$ (Newman et al. in press).

Exosphaeroma hylecoetes Barnard, 1940 is a sphaeromatid isopod with a distribution from the Olifants Estuary on the west coast to the Mkomazi Estuary on the east coast (Day 1974). Like all peracarid crustaceans, E. hylecoetes is a direct developer, i.e. it lacks free-swimming larvae. As this species is usually associated with submerged objects such as rocks, wood or vegetation, dispersal most likely takes place by means of rafting. Some peracarid crustaceans tend to be abundant on floating macroalgae that provide both a means of dispersal and a source of food, and they can persist for prolonged periods of time because their offspring may recruit directly onto the parental raft (Thiel 2003). As a large number of individuals arrive at a new habitat simultaneously, rafting species are believed to be able to colonize remote habitats more successfully than species that disperse by means of planktonic larvae, as larval densities decrease with increasing distance from the source habitat (Stoddart 1984). Dispersal by means of rafting is likely to be sporadic, and due to low levels of gene-flow among populations, the potential for founder speciation is high (Paulay \& Meyer 2002, Teske et al. 2005).

Iphinoe truncata Hale, 1953 is a cumacean that is also characterized by direct development. Its exact distribution range is unknown despite being one of the most abundant species in South African estuaries (Teske \& Wooldridge 2004), but it has been reported both on the south coast (Froneman 2001, Teske \& Wooldridge 2003, 2004) and on the east coast (Mackay \& Cyrus 2001). This species is strongly associated with sandy sediments (Teske \& Wooldridge 2004) rather than submerged objects, suggesting that dispersal by means of rafting is unlikely. However, adult cumaceans are fairly mobile, and due to the species' small size, it is possible that individuals flushed out of estuaries may disperse as part of the plankton, a notion supported by Cummings et al. (1995) who found adults of the benthic cumacean Colurostylis lemurum drifting in the water column.

Avise et al. (1987) hypothesized that species that have life histories conducive to dispersal should have limited phylogeographic structure. The amount of genetic structure along the South African coast should thus be lowest in the mudprawn (which is likely to have the highest dispersal ability) and higher in the other 2 species, as gene-flow in these species is likely to take place by means of chance dispersal (rafting or drifting of adults). In terms of genetic patterns, mudprawns should (1) be characterized by the lowest number of mtDNA lineages along the coast, (2) exhibit more gene flow across regions characterized by phylogeographic breaks than the other 2 species, and (3) show the lowest degree of isolation by distance.

\section{MATERIALS AND METHODS}

Sampling, DNA extraction, amplification and sequencing. To determine the exact locations of marine biogeographic boundaries that may influence phylogeographic patterns in the 3 estuarine crustaceans studied, a small number $(\leq 4)$ of individuals of each species was collected in as many South African estuaries as possible.

A total of 58 mudprawns, 39 isopods and 61 cumaceans were analyzed, which were collected in 21,15 , and 22 estuaries, respectively (Table 1). Muscle tissue from mudprawns was obtained either from one of the chelae or from the telson. In the case of isopods, the tip of the telson was used, and due to the small size of the cumaceans, DNA was extracted from complete specimens. Genomic DNA was isolated following the Chelex $^{\circledR}$ extraction protocol (Walsh et al. 1991) and a portion of the mitochondrial cytochrome oxidase $c$ subunit I gene (mtDNA COI) was amplified using the polymerase chain reaction (PCR). Primers were designed to anneal to regions that were relatively conserved among published COI sequences of various crustaceans (Decapoda: Penaeus monodon, accession no. AF217843; Portunus trituberculatus, AB093006; Macrobrachium rosenbergii, AY614554; Paramunida luminata, AY351035; Peracarida: Cyathura sp., AF520451.1; Cyclaspis alba, AF137517; Sphaeramene polytylotos, AF260846; Paridotea ungulata, AF255783) and included up to 3 degenerate sites. Forward primer CrustCOIF 5'-TCA ACA AAT CAY AAA GAY ATT GG-3' was used to amplify all 3 species. Reverse primers were designed to amplify taxa associated with specific crustacean suborders. The decapod Upogebia 
Table 1. Number of specimens of each species collected per estuary. Estuarine systems are listed from west to east and are grouped into biogeographic provinces following Harrison (2002). Estuary numbers correspond to the numbers used in Fig. 1. Langebaan Lagoon (Estuary no. 3) is not a true estuary as it lacks freshwater inflow, but many species common in estuaries and rare in the marine habitat occur in this system

\begin{tabular}{|c|c|c|c|c|c|}
\hline Province & $\begin{array}{c}\text { Estuary } \\
\text { no. }\end{array}$ & $\begin{array}{l}\text { Estuary } \\
\text { name }\end{array}$ & $\begin{array}{l}\text { Upogebia } \\
\text { africana }\end{array}$ & $\begin{array}{c}\text { Exosphaeroma } \\
\text { hylecoetes }\end{array}$ & $\begin{array}{l}\text { Iphinoe } \\
\text { truncata }\end{array}$ \\
\hline \multirow{5}{*}{$\begin{array}{l}\text { Cool- } \\
\text { temperate }\end{array}$} & 1 & Olifants & 4 & 4 & - \\
\hline & 2 & Groot Berg & 3 & 4 & - \\
\hline & 3 & Langebaan & 1 & - & - \\
\hline & 4 & Bot & - & 2 & - \\
\hline & 5 & Uilenkraals & 2 & 3 & - \\
\hline \multirow{26}{*}{$\begin{array}{l}\text { Warm- } \\
\text { temperate }\end{array}$} & 6 & Duiwenhoeks & 2 & - & 1 \\
\hline & 7 & Goukou & 3 & - & 4 \\
\hline & 8 & Gourits & 3 & 3 & - \\
\hline & 9 & Klein Brak & - & 1 & - \\
\hline & 10 & Groot Brak & 1 & 1 & - \\
\hline & 11 & Touws & - & - & 3 \\
\hline & 12 & Goukamma & - & - & 2 \\
\hline & 13 & Knysna & 3 & - & - \\
\hline & 14 & Piesang & - & 2 & - \\
\hline & 15 & Keurbooms & 3 & 3 & 4 \\
\hline & 16 & Groot & - & - & 2 \\
\hline & 17 & Kromme & - & - & 3 \\
\hline & 18 & Seekoei & - & 3 & - \\
\hline & 19 & Kabeljous & - & - & 2 \\
\hline & 20 & Van Stadens & - & - & 4 \\
\hline & 21 & Swartkops & 3 & - & - \\
\hline & 22 & Sundays & 3 & - & 4 \\
\hline & 23 & Boknes & - & 3 & 3 \\
\hline & 24 & Great Fish & 4 & - & - \\
\hline & 25 & Mpekweni & - & 3 & 3 \\
\hline & 26 & Gqunube & 4 & - & 2 \\
\hline & 27 & Haga-Haga & 4 & 3 & 2 \\
\hline & 28 & Qora & 2 & 2 & - \\
\hline & 29 & Ku-Mpenzu & - & - & 2 \\
\hline & 30 & Mbhanyana & 2 & - & - \\
\hline & 31 & Bulolo & 3 & 2 & 3 \\
\hline \multirow{9}{*}{$\begin{array}{l}\text { Sub- } \\
\text { tropical }\end{array}$} & 32 & Ku-Boboyi & - & - & 3 \\
\hline & 33 & Mpenjati & 3 & _- & - \\
\hline & 34 & Mzimkulu & 2 & - & - \\
\hline & 35 & Mtentweni & - & - & 4 \\
\hline & 36 & Mkomazi & 3 & - & - \\
\hline & 37 & Ngane & - & - & 2 \\
\hline & 38 & Tongati & - & - & 1 \\
\hline & 39 & Zinkwazi & - & - & 3 \\
\hline & 40 & Kosi & - & - & 4 \\
\hline
\end{tabular}

africana was amplified with reverse primer DecapCOIR 5'-AAT TAA AAT RTA WAC TTC TGG-3', and PeracCOIR 5'-TAT WCC TAC WGT RAA TAT ATG ATG-3' was used to amplify the 2 peracarids E. hylecoetes and I. truncata. Each $50 \mu \mathrm{l}$ PCR reaction contained $5 \mu$ l of $10 \times \mathrm{NH}_{4}$ reaction buffer (Bioline), $6 \mathrm{mM}$ of $\mathrm{MgCl}_{2}, 0.16 \mathrm{mM}$ of each dNTP (Bioline), $3 \mathrm{pmol} \mathrm{ul}^{-1}$ of each primer, $0.2 \mu \mathrm{l}$ of BIOTAQ ${ }^{\mathrm{TM}}$ DNA Polymerase (5 units $\mu \mathrm{l}^{-1}$, Bioline) and $2 \mu \mathrm{l}$ of DNA extracts. Samples that were difficult to amplify additionally included
0.2 to $0.5 \mu \mathrm{l}$ of $10 \mathrm{mg} \mathrm{ml}^{-1}$ Bovine Serum Albumin solution. The PCR profile comprised an initial denaturation step (3 min at $94^{\circ} \mathrm{C}$ ), 35 cycles of denaturation $\left(30 \mathrm{~s}\right.$ at $\left.94^{\circ} \mathrm{C}\right)$, annealing $(45 \mathrm{~s}$ at 45 to $\left.50^{\circ} \mathrm{C}\right)$ and extension $(75 \mathrm{~s}$ at $72^{\circ} \mathrm{C}$ ), and a final extension step $\left(10 \mathrm{~min}\right.$ at $\left.72^{\circ} \mathrm{C}\right)$. PCR products were purified with the Wizard ${ }^{\circledR} \mathrm{SV}$ Gel and PCR Clean-Up System (Promega), cycle-sequenced both in the forward and reverse direction using a BigDye ${ }^{\circledR}$ Terminator v3.1 Cycle Sequencing Kit (Applied Biosystems) and visualized on an ABI 3100 genetic analyser.

Data analyses. Partial COI sequences 642, 616 and 590 nucleotides in length were obtained for isopods, cumaceans and mudprawns, respectively, resulting in 29, 35 and 48 unique haplotypes. These have been deposited in GenBank (accession nos.: Exosphaeroma hylecoetes: DQ070257-DQ070285; Iphinoe truncata: DQ070286-DQ070320; Upogebia africana: DQ070321-DQ070338). The majority of variable characters in all 3 species were found in third character positions (E. hylecoetes: 77; I. truncata: $87 \%$; U. africana: $87 \%$ ). This, and the absence of double bands, stop codons, indels and chromatogram peaks of equal intensity at the same positions, indicates that the amplified products are likely to be of mitochondrial origin.

Genealogy reconstructions. The neighbour-joining method (Saitou \& Nei 1987) was used to reconstruct genealogical relationships among the haplotypes of each species. The most appropriate model of sequence evolution was determined for each species using the Akaike Information Criterion (AIC) as implemented in the program MODELTEST version 3.06 (Posada \& Crandall 1998), and was incorporated into genealogical reconstructions performed using PAUP* version $4.0 \mathrm{~b} 10$ (Swofford 2002). The neighbour-joining tree of Upogebia africana was rooted with $U$. capensis (accession no. DQ070369). Congeners of Exosphaeroma hylecoetes and Iphinoe truncata were genetically highly divergent. As long outgroup branches can result in spurious rooting (e.g. Felsenstein 1978, Wheeler 1990), midpoint rooting was applied instead. Clade support was obtained from 1000 bootstrap replicates. The location of phylogeo- 
graphic breaks among different mtDNA lineages of each species were visualized by plotting the distributions of each of these lineages onto a map.

Divergence time estimates. Rough estimates of minimum divergence times among lineages within each species were made by comparing the smallest genetic distances among any 2 lineages with those of 2 sister-species of the snapping shrimp genus Alpheus (A. estuarensis, AF097860 and A. colombiensis, AF097861; Knowlton \& Weigt 1998), which are believed to have diverged as a result of the final closure of the Central American Seaway (approximately 3.1 million yr ago [mya], Coates et al. 1992).

Isolation by distance. Several of the mtDNA lineages identified using genealogical reconstructions were examined for isolation by distance. The effect of geographic distance on genetic differentiation between populations was investigated by calculating pairwise $\Phi_{\mathrm{ST}}$ values (Excoffier et al. 1992) among populations associated with specific lineages of a particular species and determining whether these were correlated with the shortest possible geographic distances between any 2 estuaries. $\Phi_{\mathrm{ST}}$ values were estimated based on p-distances using the program ARLEQUIN version 2.001 (Schneider et al. 2000, including 2 updated files released in 2001). Associations between matrices comprising pairwise $\Phi_{\mathrm{ST}}$ values and corresponding pairwise geographic distances among estuaries were then tested by performing Mantel tests using the program MANTEL for Windows version 1.16 (Cavalcanti 2005). The significance of the Mantel statistic $Z$ is tested by a permutation procedure in which values in one data matrix are randomly reshuffled (20 000 permuted data-sets were created).

\section{RESULTS}

\section{Genealogy reconstructions and phylogeographic patterns}

Neighbour-joining trees reconstructed from crustacean COI sequences recovered between 2 and 3 wellsupported clades (Fig. 2). Their distributions are shown
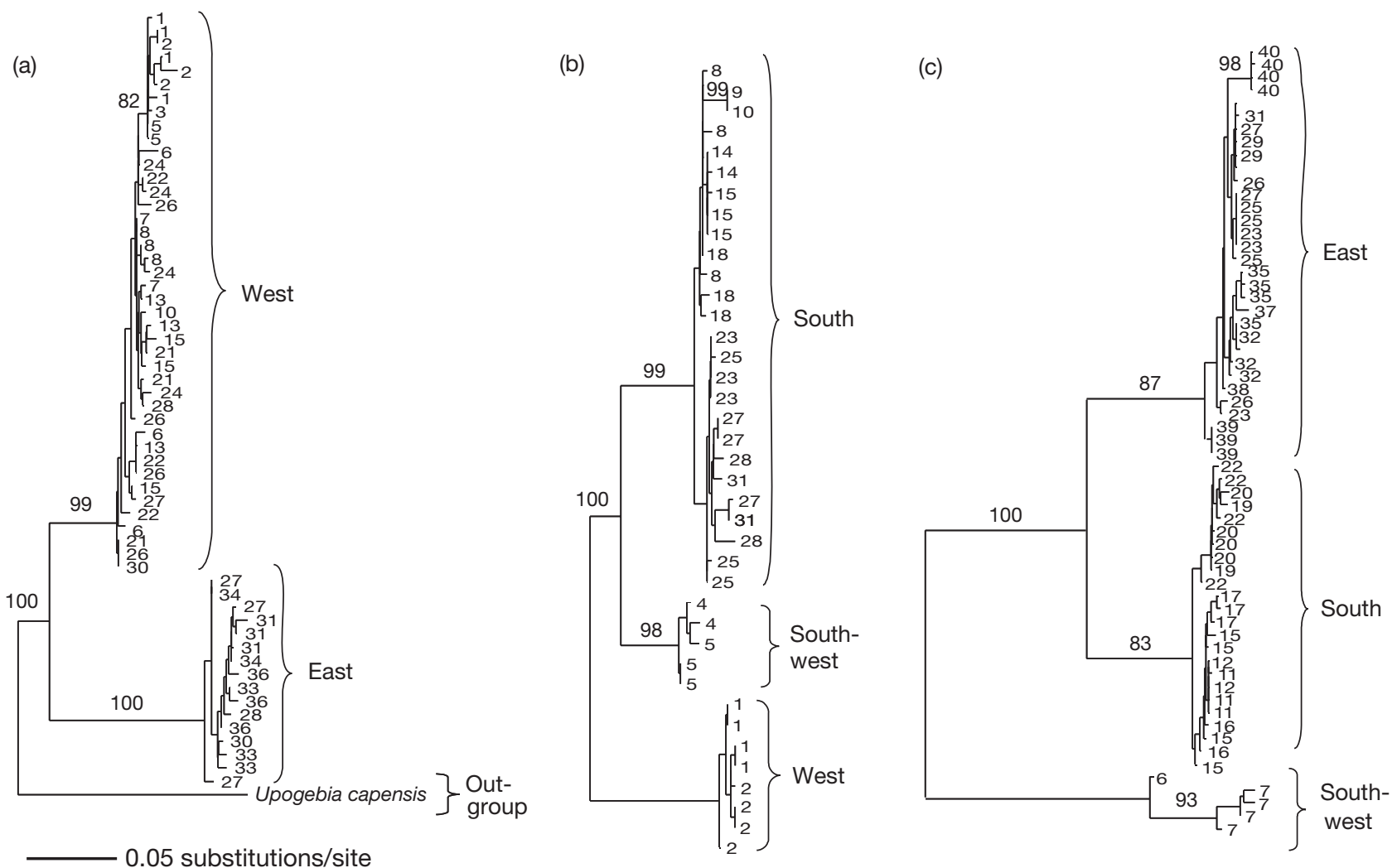

Fig. 2. Upogebia africana, Exosphaeroma hylecoetes and Iphinoe truncata. Neighbour-joining phylograms constructed from COI sequences of 3 South African estuarine crustaceans. (a) $U$. africana (mudprawn); model selected: HKY $+\mathrm{I}+\Gamma$ (Hasegawa et al. 1985); phylogram rooted with $U$. capensis; (b) E. hylecoetes (isopod); model selected: HKY $+\Gamma$; midpoint-rooted phylogram; (c) I. truncata (cumacean); model selected: HKY $+\mathrm{I}+\Gamma$; midpoint-rooted phylogram. Gamma distribution parameters $(\alpha)$ estimated in MODELTEST were 0.80 for $U$. africana, 0.16 for E. hylecoetes and 0.39 for $I$. truncata. Clade support from 1000 bootstrap replications (>80\%) was added to some branches; the bootstrap consensus tree of $U$. africana was rooted by means of an outgroup, whereas the other 2 trees were unrooted. See Table 1 for the names of estuarine systems represented by numbers 


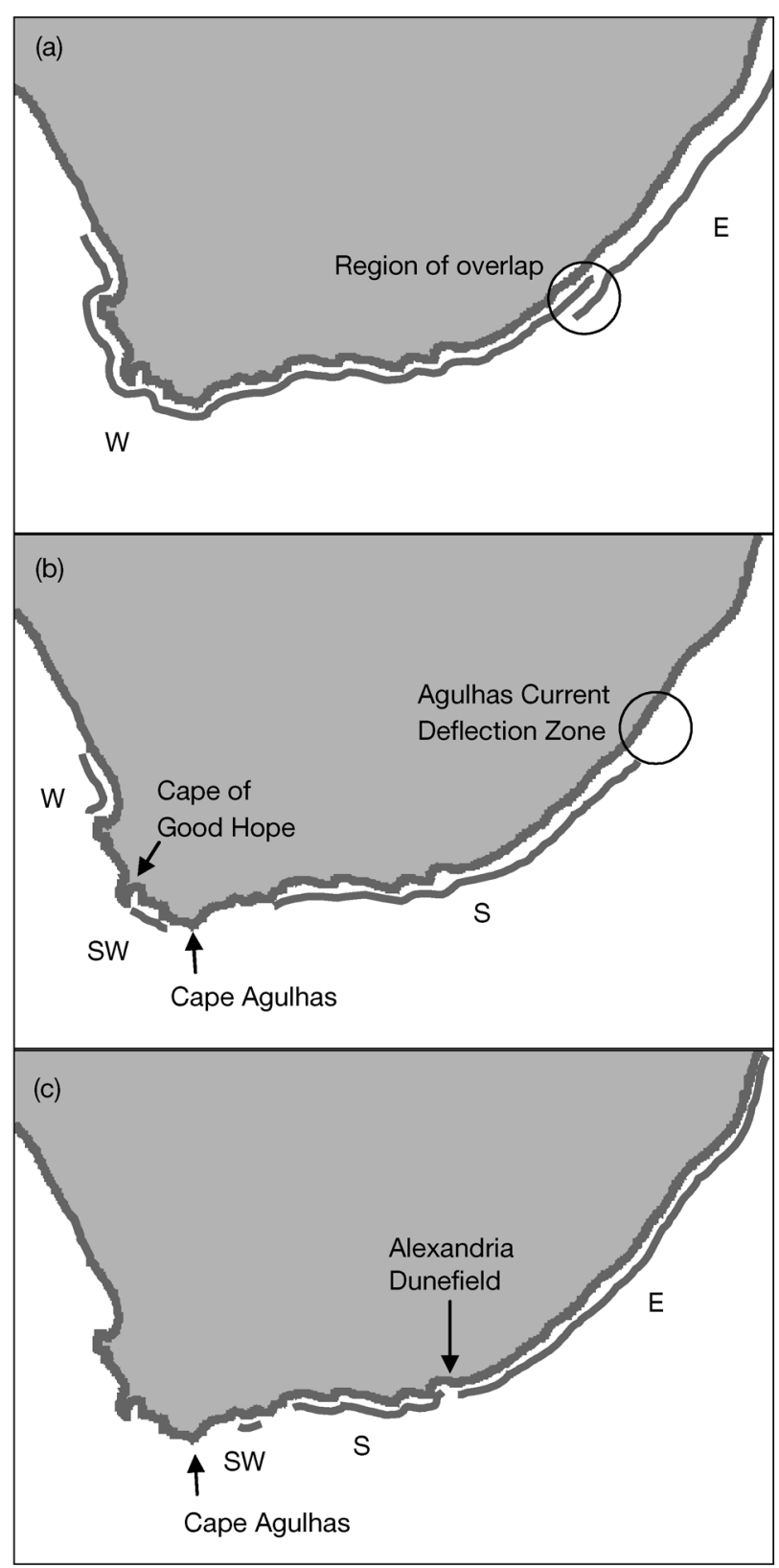

Fig. 3. Upogebia africana, Exosphaeroma hylecoetes and Iphinoe truncata. Distribution patterns of the mtDNA lineages of 3 estuarine crustaceans along the South African coast. (a) U. africana, (b) E. hylecoetes, (c) I. truncata. Descriptions of the geographic associations of individual lineages correspond to those used in Fig. 2. W: West; SW: Southwest; S: South; E: East

in Fig. 3. The mudprawn Upogebia africana comprised 2 major mtDNA lineages (Fig. 2a), one of which included samples from the Olifants Estuary to the Mbhanyana Estuary (west coast to southeast coast), and the other occurred from the Haga-Haga Estuary to the Mkomazi Estuary (southeast coast to east coast).
The fact that the Haga-Haga Estuary is located south of the Mbhanyana Estuary indicates that the distributions of the 2 mudprawn lineages overlap on the southeast coast. There was also high bootstrap support for the monophyly of specimens originating from estuaries located west of Cape Agulhas.

Three major mtDNA lineages were recovered in the isopod Exosphaeroma hylecoetes (Fig. 2b): (1) a southern lineage occurred from the Gourits Estuary (east of Cape Agulhas) to the Bulolo Estuary (near Port St. Johns), (2) a south-western lineage was represented by individuals collected in 2 estuaries located between Cape Agulhas and the Cape of Good Hope, and (3) 2 populations west of the Cape of Good Hope represented a western lineage. No regions of overlap were identified.

The neighbour-joining tree of the cumacean Iphinoe truncata also comprised 3 major mtDNA lineages (Fig. 2c). The basal lineage was represented by specimens collected in 2 estuaries located east of Cape Agulhas (Duiwenhoeks and Goukou). The distributions of the other 2 lineages ranged from the Touws Estuary to the Sundays Estuary (southern lineage) and from the Boknes Estuary to the Kosi Estuary (eastern lineage), respectively. As for Exosphaeroma hylecoetes, the distributions of the 3 I. truncata lineages did not overlap.

\section{Divergence time estimates}

Approximate minimum divergence time estimates among crustacean lineages were calculated using HKY distances, as variants of this model were selected by MODELTEST for all 3 crustacean species. The pairwise HKY distance of the 2 Alpheus species used for calibration was 0.062 , and they diverged at least 3.1 mya. An HKY distance of 0.02 per million yr was consequently used to estimate minimum divergence times in the 3 South African crustaceans. These ranged from 2 mya in the southern versus southwestern lineage of Exosphaeroma hylecoetes, to 6.5 mya in the southwestern lineage of Iphinoe truncata versus the other 2 lineages (Table 2).

\section{Isolation by distance}

Five of the lineages identified using genealogy reconstruction (2 mudprawn lineages, 1 isopod lineage and 2 cumacean lineages) were analyzed for isolation by distance. Significant isolation by distance was found among populations of the southern lineage of Exosphaeroma hylecoetes and among populations of the eastern lineage of Iphinoe truncata (Table 3). The 
Table 2. Minimum HKY distances and estimates of divergence times among clades of mtDNA lineages of 3 South African estuarine crustaceans. Divergence times were calculated based on an HKY distance of 0.02 per million yr

\begin{tabular}{|lllcc|}
\hline Species & Clade 1 & Clade 2 & $\begin{array}{c}\text { HKY } \\
\text { distance }\end{array}$ & $\begin{array}{c}\text { Divergence time } \\
\text { (mya) }\end{array}$ \\
\hline Upogebia africana & West & East & 0.06 & 3.0 \\
Exosphaeroma & South & Southwest & 0.04 & 2.0 \\
hylecoetes & West & Southwest/South & 0.05 & 2.5 \\
Iphinoe truncata & East & South & 0.06 & 3.0 \\
& Southwest & South/East & 0.13 & 6.5 \\
\hline
\end{tabular}

Table 3. Results of Mantel tests on matrices of genetic differentiation among populations (pairwise $\Phi_{\mathrm{ST}}$ using p-distances) and geographic distance of 5 mtDNA lineages identified using genealogy reconstructions (Fig. 2a-c). Values were transformed prior to analysis by taking the inverse of squared distances. r: Pearson product-moment correlation (shown instead of the Mantel $Z$ statistic for simplicity of interpretation); $t$ : approximate Mantel $t$-test statistic; p: probability that random $Z<$ observed $Z$

\begin{tabular}{|llrrr|}
\hline Species & \multicolumn{1}{c}{ Grouping } & $r$ & $t$ & $\mathrm{p}$ \\
\hline $\begin{array}{l}\text { Upogebia } \\
\text { africana }\end{array}$ & Western lineage (Olifants to Mbhanyana) & -0.07 & -0.88 & 0.19 \\
$\begin{array}{l}\text { Exosphae- } \\
\text { roma }\end{array}$ & Southern lineage (Gourits to Bulolo) & -0.25 & -1.81 & 0.04 \\
hylecoetes & & & & \\
$\begin{array}{l}\text { Iphinoe } \\
\text { truncata }\end{array}$ & Southern lineage (Touws to Sundays) & -0.30 & -1.52 & 0.06 \\
& Eastern lineage (Boknes to Kosi) & -0.22 & -1.95 & 0.03 \\
\hline
\end{tabular}

Mantel test was marginally non-significant for the southern I. truncata lineage, and the highest p-values were found in the 2 mudprawn lineages.

\section{DISCUSSION}

\section{Phylogeographic patterns}

The extent of gene-flow within mtDNA lineages of the 3 estuarine crustaceans differed on the basis of their modes of dispersal. Estimates of isolation by distance were lower in the potentially good disperser Upogebia africana than in the 2 peracarid crustaceans. Two major mtDNA lineages were identified in $U$. africana and 3 each in the other 2 species. The location of phylogeographic breaks corresponded to biogeographic boundaries in 2 of the species studied.

\section{Western boundaries}

A boundary near Cape Agulhas affected all 3 species, but its relative importance differed. In the mudprawn Upogebia africana specimens collected west of
Cape Agulhas comprised a monophyletic lineage that was, however, not strongly differentiated from specimens collected east of the boundary. As mudprawn larvae have comparatively high dispersal abilities (confirmed by the absence of isolation by distance within lineages), it is possible that COI alleles shared between the 2 regions would be detected if sample sizes were increased. This is supported by the fact that the South African abalone Haliotis midae (also a planktonic disperser) comprises 2 reproductive stocks, which are separated by Cape Agulhas and share some haplotypes (Evans et al. 2004). In contrast to these 2 planktonic dispersers, the isopod Exosphaeroma hylecoetes showed considerable genetic differentiation across the Cape Agulhas boundary, and a second phylogeographic break was found in the region between Cape Columbine (Boundary A on Fig. 1) and the Cape of Good Hope. The effect of the Cape Agulhas boundary was strongest on the cumacean Iphinoe truncata, which was not found west of it. In addition, a boundary east of Cape Agulhas (between the Goukou and Touws Estuaries) was detected in I. truncata. There are several estuarine systems between the latter 2 estuaries (Gourits, Hartenbos, Klein Brak and Groot Brak) where this species was not found despite extensive sampling but may nonetheless occur, so the exact position of this barrier is not certain.

\section{Eastern boundaries}

There was evidence of an eastern boundary separating the warm-temperate and subtropical provinces in the mudprawn and in the isopod, with the mudprawn being characterized by a distinct eastern lineage and the isopod being absent from much of the east coast. The continental shelf is narrow along South Africa's east coast (3 to $40 \mathrm{~km}$, Flemming 1981). It is only about $12.5 \mathrm{~km}$ wide at Port St. Johns (Fig. 1) and then gradually widens, deflecting the warm, southward-flowing Agulhas Current away from the coast (Heydorn et al. 1978). Previous studies attributed changes in species compositions in this region to temperature changes (e.g. Stephenson \& Stephenson 1972, Wallace \& van der Elst 1975). It also seems plausible that the Agulhas Current Deflection Zone functions as a mechanical 
barrier by limiting northward movement of temperate species. For example, northward transport of mudprawn larvae originating from the western lineage seems to be comparatively rare, whereas southward transport is much more common, resulting in the observed overlap of the 2 lineages as far south as approximately East London (Boundary B on Fig. 1). Similar phylogeographic patterns were found in the limpet Patella granularis (Ridgway et al. 1998) and in the mussel Perna perna (G. I. Zardi unpubl. data), both species characterized by planktonic dispersal. No evidence for genetic discontinuity near the Agulhas Current Deflection Zone was found in the cumacean Iphinoe truncata, but a boundary was detected south of this region, between the Sundays and Boknes Estuaries. Located between these 2 estuaries is the Alexandria Coastal Dunefield, one of the largest coastal dunefields in the world (Illenberger 1993). It is possible that the comparatively large distance between the 2 estuaries and the lack of suitable habitat along the dunefield constitutes a dispersal barrier to I. truncata. It is also possible that the strong southwesterly winds that blow perpendicular to the dunefield and provide it with sand (Illenberger \& Rust 1988) prevent drifting of cumaceans along the coast.

\section{Ecological causes of cladogenesis}

Divergence events evident in the genealogies reconstructed from COI sequences all predated the onset of the present climate optimum (approximately $6000 \mathrm{yr}$ ago, Lindesay 1998) and thus cannot be explained by present-day environmental conditions.

Vicariance is likely to be the predominant mechanism of speciation (and cladogenesis) in the sea (Santini \& Winterbottom 2002), and several authors have stressed the importance of tectonic events in determining distribution patterns of coastal organisms (Springer 1999, Orrell et al. 2002). However, no major geological changes occurred along the South African coastline since the break-up of western Gondwana and the formation of the present continental shelf during the early Cretaceous (Heydorn et al. 1978), and there is no evidence of a geological feature that could have acted as an absolute barrier to the dispersal of estuarine crustaceans during the glacial and interglacial phases.

Broadly, the distributions of the main mtDNA lineages of Upogebia africana and Exosphaeroma hylecoetes correspond with present-day biogeographic regions, and the most obvious explanation for their divergence may be different selective forces imposed on regional populations as a result of different environmental conditions. Even in large populations that are not completely isolated from each other, selection may result in a shift in gene frequencies (reviewed in Palumbi 1994), which may eventually result in parapatric speciation. Bolton \& Anderson (1990) showed that the ranges of seaweed species and the structure and composition of seaweed communities in South Africa are correlated with water temperature. It is possible that individual evolutionary units within species respond similarly, so that some of the crustacean mtDNA lineages identified in this study are adapted to different temperature regimes.

Although the genetic divergences observed may be partially explained by adaptation, mode of dispersal is also likely to have played a role in driving cladogenesis. For example, the fact that there are phylogeographic breaks in 2 geographically close areas of the temperate region in the rafting species Exosphaeroma hylecoetes, but little genetic structuring in Upogebia africana, is probably due to differences in dispersal mode. Analyses of the southern lineage of E. hylecoetes indicated that isolation by distance affects population interactions. While large numbers of planktonic larvae are released into the coastal region, rafting is likely to be comparatively rare, resulting in greater genetic subdivision.

\section{Present-day phylogeographic patterns}

Despite ancient divergence times among mtDNA lineages of the study species, the effects of present-day environmental conditions on phylogeographic patterns are nonetheless important. Fossil data indicate that during the last interglacial, when sea surface temperatures were higher than they are during the present interglacial (southwest coast: $+3.8^{\circ} \mathrm{C}$; southeast coast: $+0.9^{\circ} \mathrm{C}$, Crowley \& North 1991), the distributions of species presently confined to the warmer waters of the east coast extended close to Cape Agulhas (Martin 1962, Davies 1971), and some south coast species were present on the west coast (Grindley et al. 1989). Genetic lineages adapted to regional environmental conditions would similarly be expected to adjust to large-scale changes in climatic conditions. Particularly in species with high dispersal abilities (e.g. mudprawns), distributions of lineages should thus largely reflect present-day environmental conditions.

The majority of genetic studies on marine animals have found correlations between phylogeographic patterns and biogeographic patterns (e.g. Avise et al. 1987, Dawson 2001, Waters \& Roy 2003). Such patterns can usually be explained by present-day environmental conditions, but there are some notable exceptions in which past phylogeographic patterns are likely to have been retained, e.g. in west Pacific giant clams Tridacna 
maxima (Benzie \& Williams 1997) and in the southern Australian gastropod Nerita atramentosa (Waters et al. 2005). For example, the distributions of the eastern and western lineages of $N$. atramentosa are not defined by water temperature (both lineages occur in both warm and cool temperate waters), but by a geological feature that does not represent a barrier to gene-flow during the present interglacial phase.

The patterns observed in the cumacean Iphinoe truncata in the present study provide a further example of a species whose phylogeographic patterns do not match present-day biogeographic patterns; the breaks between its mtDNA lineages were found at different localities from those of the other 2 species, and they were found in regions where no biogeographic boundaries have been proposed in the literature. Although the observed phylogeographic break between the southern and eastern lineages of $I$. truncata coincides with the Alexandria Coastal Dunefield, high genetic distances between these lineages indicate that genetic divergence is likely to have occurred prior to the formation of the dunefield (approximately $6500 \mathrm{yr}$ ago). A possible explanation is the presence of coastal dunefields in the same locality during previous interglacial periods (W. K. Illenberger pers. comm.). The second phylogeographic break in I. truncata was found in a region that is characterized by similar geological formations as the region where the Alexandria Dunefield is presently located (Maud \& Botha 2000). Thus, the observed genetic discontinuity east of Cape Agulhas may also be the result of vicariance caused by the formation of a dunefield formerly present in this region. Interestingly, the Agulhas Current Deflection Zone, which strongly affected the other 2 species, had no detectable influence on the phylogeography of I. truncata. This species may have undergone a recent population expansion in this region so that the observed pattern is the result of recent common ancestry, rather than extensive gene-flow. Signatures of ancient distributions of mtDNA lineages are thus more likely to persist in this poorly dispersing species than in the 2 other crustaceans studied, and recently established distributions may not yet have manifested themselves in phylogeographic patterns detectable at the mtDNA level. More intensive sampling and the use of more rapidly evolving markers (e.g. microsatellites) are required to determine whether a phylogeographic break has as yet developed in the Agulhas Current Deflection Zone.

\section{Directions for future research}

This study on South African estuarine crustaceans investigated how ecological and historical factors affect phylogeographic patterns. Most genetic studies on South African coastal species have employed allozyme electrophoresis and failed to find significant genetic structure, although morphological and behavioral differentiation among regional populations was evident in some cases (e.g. Grant et al. 1992, Grant \& da Silva-Tatley 1997, Ridgway et al. 1999). Evans et al. (2004) showed that mtDNA or microsatellites have greater potential to detect genetic structure, but little phylogeographic work using these markers has been done to date (e.g. Teske et al. 2003, Evans et al. 2004, Tolley et al. 2005). To establish whether the results of this study on estuarine crustaceans may be generally applicable to species characterized by similar life histories and ecologies, sequence data from additional coastal taxa are required.

Species with good dispersal abilities are often believed to have greater distribution ranges than poorly-dispersing species (e.g. Scheltema 1986, Jablonski 1986), but this notion has been questioned (reviewed in Head 2005). The results of our study indicate that, although there was evidence that gene flow within mtDNA lineages is dependent on a species' mode of dispersal, the extent of the geographic ranges these lineages occupy and the number of lineages identified per species did not differ much. This suggests that in the absence of dispersal barriers, even poorly-dispersing estuarine species can maintain sufficient gene-flow to prevent genetic divergence. Instead, distributions of mtDNA lineages occurring in parapatry may be defined by environmental conditions. Using allozyme data, Ridgway et al. (1998) found 2 genetic lineages of the planktonic disperser Patella granularis, with distributions similar to those identified for Upogebia africana in this study, including a region of overlap in the southeast. As none of the individuals collected had alleles from both lineages, it was concluded that they are reproductively isolated and should be considered biological species. There was also evidence of morphological differentiation. It is likely that many coastal South African species with supposedly large distribution ranges actually comprise 2 or more cryptic species, which are mutually exclusive because of competition for similar ecological niches. Future studies could determine whether (1) the regional crustacean mtDNA lineages identified in this study are reproductively isolated (either by performing breeding experiments in the laboratory or by sequencing nuclear genetic markers), (2) whether there are previously unnoticed morphological differences, and (3) whether adaptations to different climatic conditions are evident (by investigating e.g. whether mudprawns from the east coast have higher optimum temperatures for growth and development). 
Acknowledgements. We are grateful to P. Cowley and P. Nel for providing us with samples of Upogebia africana and U. capensis from Langebaan Lagoon, to E. Teske, Z. Weight, I. Jastram, G. Schäfer, G. I. Zardi, K. Nicastro and O. Norton for helping with the sampling, and to W. K. Illenberger for information concerning the Alexandria Coastal Dunefield. N. Devos, P. C. Dworschak, I. Papadopoulos and 5 anonymous referees are thanked for comments on an earlier version of the manuscript. This study was supported by a Claude Harris Leon Postdoctoral Research Fellowship awarded to P.R.T., the the National Research Foundation (GUN 2069119) and Rhodes University.

\section{LITERATURE CITED}

Avise JC, Arnold J, Ball RM, Bermingham E, Lamb T, Neigel JE, Reeb CA, Saunders NC (1987) Intraspecific phylogeography: the mitochondrial DNA bridge between population genetics and systematics. Annu Rev Ecol Syst 18: 489-522

Beckley LE, van Ballegooyen RC (1992) Oceanographic conditions during three ichthyoplankton surveys of the Agulhas Current in 1990/91. S Afr J Mar Sci 12:83-93

Benzie JAH, Williams ST (1997) Gene flow among giant clam (Tridacna maxima) populations in the west Pacific is not consistent with dispersal by present-day ocean currents. Evolution 51:768-783

Bolton JJ, Anderson RJ (1990) Correlation between intertidal seaweed community composition and sea water temperature patterns on a geographic scale. Bot Mar 33:447-457

Bolton JJ, Leliaert F, de Clerck O, Anderson RJ, Stegenga H, Engledow HE, Coppejans E (2004) Where is the western limit of the tropical Indian Ocean seaweed flora? An analysis of intertidal seaweed biogeography on the east coast of South Africa. Mar Biol 144:51-59

Cavalcanti MJ (2005) MANTEL for Windows version 1.16 test for association between two symmetric distance matrices with permutation iterations. Departemento de Vertebrados, Museum Nacional de Rio de Janeiro, Brazil. Software available at http://life.bio.sunysb.edu/morph/

Coates AG, Jackson JBC, Collins LS, Cronin TM, Dowsett HJ, Bybell LM, Jung P, Obando JA (1992) Closure of the Isthmus of Panama: the near-shore marine record of Costa Rica and Panama. Geol Soc Am Bull 104:814-828

Collin R (2001) The effects of mode of development on phylogeography and population structure of North Atlantic Crepidula (Gastropoda: Calyptraeidae). Mol Ecol 10: 2249-2262

Crowley TJ, North GR (1991) Paleoclimatology-Oxford monographs on geology and geophysics, no. 18. Oxford University Press, New York

Cummings VJ, Pridmore RD, Thrush SF, Hewitt JE (1995) Post-settlement movement by intertidal benthic macroinvertebrates: Do common New Zealand species drift in the water column? NZ J Mar Freshw Res 29:59-67

Davies O (1971) Pleistocene shorelines in the southern and south-eastern Cape Province (Part 1). Ann Nat Mus 20: 403-442

Dawson MN (2001) Phylogeography in coastal marine animals: a solution from California? J Biogeogr 28:723-736

Dawson MN, Jacobs DK (2001) Molecular evidence for cyptic species of Aurelia aurita (Cnidaria, Scyphozoa). Biol Bull 200:92-96

Day JH (1974) A guide to marine life on South African shores. AA Balkema, Cape Town

de Villiers CJ, Hodgson AN, Forbes AT (1999) Studies on estuarine macroinvertebrates. In: Allanson BR, Baird D (eds) Estuaries of South Africa. Cambridge University Press, Cambridge, p 167-207

Emanuel BP, Bustamante RH, Branch GM, Eekhout S, Odendaal FJ (1992) A zoogeographic and functional approach to the selection of marine reserves on the west coast of South Africa. S Afr J Marine Sci 12:341-354

Evans BS, Sweijd NA, Bowie RCK, Cook PA, Elliott NG (2004) Population genetic structure of the perlemoen, Haliotis midae in South Africa: evidence of range expansion and founder events. Mar Ecol Prog Ser 270:163-172

Excoffier L, Smouse PE, Quattro JM (1992) Analysis of molecular variance inferred from metric distances among DNA haplotypes: application to human mitochondrial DNA restriction data. Genetics 131:479-491

Felsenstein J (1978) Cases in which parsimony and compatibility methods will be positively misleading. Syst Zool 27 : 401-410

Flemming BW (1981) Factors controlling shelf sediment dispersal along the southeast African continental margin. Mar Geol 42:259-277

Froneman PW (2001) Stable isotope $\left(\delta^{13} \mathrm{C}\right)$ composition of the food web of the temperate Kariega estuary (Eastern Cape). Afr J Aquat Sci 26:49-56

Grant WS, da Silva-Tatley FM (1997) Lack of genetically-subdivided population structure in Bullia digitalis, a southern African marine gastropod with lecithotrophic development. Mar Biol 129:123-137

Grant WS, Schneider AC, Leslie RW, Cherry MI (1992) Population genetics of the brown mussel Perna perna in southern Africa. J Exp Mar Biol Ecol 165:45-58

Griffiths CL (1976) Guide to the benthic marine amphipods of southern Africa. The Rustica Press, Wynberg, Cape

Grindley JR, Rogers J, Pether J, Woodborne MW (1989) Holocene evolution of Rietvlei near Cape Town deduced from the palaeoecology of some mid-Holocene estuarine mollusca. Palaeoecol Afr 19:347-353

Harrison TD (2002) Preliminary assessment of the biogeography of fishes in South African estuaries. Mar Freshwater Res 53:479-490

Hasegawa M, Kishino K, Yano T (1985) Dating the humanape splitting by a molecular clock of mitochondrial DNA. J Mol Evol 22:160-174

Head M (2005) Towards a panbiogeography of the sea. Biol J Linn Soc 84:675-723

Heydorn AEF, Bang ND, Pearce AF, Flemming BW and 9 others (1978) Ecology of the Agulhas Current region: an assessment of biological responses to environmental parameters in the south-west Indian Ocean. Trans R Soc S Afr 43:151-190

Illenberger WK (1993) Wind, sand and sea: why the ACD? In: McGwynne LE (ed) Management and conservation of the Alexandria Coastal Dunefield; Proceedings of a workshop held by the Institute for Coastal Research and Cape Nature Conservation at the Sundays River Mouth Research Station on 9 June 1993; compiled by WK Illenberger and GIH Kerley. Institute for Coastal Research, University of Port Elizabeth, Report No. 35, p 9-10

Illenberger WK, Rust IC (1988) A sand budget for the Alexandria coastal dunefield, South Africa. Sedimentology 35: 513-521

Jablonski D (1986) Larval ecology and macroevolution in marine invertebrates. Bull Mar Sci 39:565-587

Jiang L, Wu WL, Huang PC (1995) The mitochondrial DNA of Taiwan abalone Haliotis diversicolor Reeve, 1846 (Gastropoda: Archaeogastropoda: Haliotidae). Mol Mar Biol Biotech 4:353-364 
Knowlton N (2000) Molecular genetic analyses of species boundaries in the sea. Hydrobiologia 420:73-90

Knowlton N, Weigt LA (1998) New dates and new rates for divergence across the Isthmus of Panama. Proc R Soc Lond B 265:2257-2263

Kyle CJ, Boulding EG (2000) Comparative population genetic structure of marine gastropods (Littorina spp.) with and without pelagic larval dispersal. Mar Biol 137:835-845

Lindesay J (1998) Past climates in Africa. In: Hobbs JE, Lindesay JA, Bridgman HA (eds) Climates of southern continents: present, past and future. John Wiley \& Sons, New York, p 161-206

Mackay CR, Cyrus DP (2001) Is freshwater quality adequately defined by physico-chemical components? Results from two drought-affected estuaries on the east coast of South Africa. Mar Freshw Res 52:267-281

Martin ARH (1962) Evidence relating to the Quaternary history of the Wilderness Lakes. Trans Geol Soc S Afr 65: $19-42$

Maud RR, Botha GA (2000) Deposits of the south eastern and southern coasts. In: Partridge TC, Maud RR (eds) The Cenozoic of southern Africa. Oxford University Press, New York, p 19-32

Orrell TM, Carpenter KE, Musick JA, Graves JE (2002) Phylogenetic and biogeographic analysis of the Sparidae (Perciformes: Percoidei) from cytochrome $b$ sequences. Copeia 2002:618-631

Palumbi SR (1994) Genetic divergence, reproductive isolation, and marine speciation. Annu Rev Ecol Syst 25: $547-572$

Paulay G, Meyer C (2002) Diversification in the tropical Pacific: comparisons between marine and terrestrial systems and the importance of founder speciation. Integr Comp Biol 42:922-934

Posada D, Crandall KA (1998) MODELTEST: testing the model of DNA substitution. Bioinformatics 14:817-818

Ridgway TM, Stewart BA, Branch GM, Hodgson AN (1998) Morphological and genetic differentiation of Patella granularis (Gastropoda: Patellidae): recognition of two sibling species along the coast of southern Africa. J Zool Lond 245:317-333

Ridgway TM, Stewart BA, Branch GM (1999) Limited population differentiation in the bearded limpet Patella barbara (Gastropoda: Patellidae) along the coast of South Africa. J Mar Biol Assoc UK 79:639-651

Riginos C, Victor BC (2001) Larval spatial distributions and other early life-history characteristics predict genetic differentiation in eastern Pacific blennoid fishes. Proc R Soc Lond B 268:1931-1936

Saitou N, Nei M (1987) The neighbor-joining method: a new method for reconstructing phylogenetic trees. Mol Biol Evol 4:406-425

Santini F, Winterbottom R (2002) Historical biogeography of Indo-western Pacfic coral reef biota: is the Indonesian region a centre of origin? J Biogeogr 29:189-205

Scheltema RS (1986) On dispersal and planktonic larvae of benthic invertebrates: an eclectic overview and summary of problems. Bull Mar Sci 39:290-322

Schneider S, Roessli D, Excoffier L (2000) ARLEQUIN version 2.000: software for population genetic analysis. Genetics and biometry laboratory, University of Geneva

Sink KJ, Harris J, Lombard A (2004) South African marine bioregions. South African National Spatial Biodiversity Assessment 2004: Technical Report Vol. 4, Marine Component
Springer VG (1999) Ecsenius polystictus, a new species of blenniid fish from Mentawai Islands, Indonesia, with notes on other species of Ecsenius. Rev Franc Aquariol 16:39-48

Stephenson TA, Stephenson A (1972) Life between tidemarks on rocky shores. WH Freeman, San Francisco, CA

Steyn DG, Lussi M (1998) Marine shells of South Africa — an illustrated collector's guide to beached shells. Ekogilde Publishers, Hartebeespoort, South Africa

Stoddart JA (1984) Genetic differentiation amongst populations of the coral Pocillopora damicornis off southwestern Australia. Coral Reefs 3:149-156

Swofford DL (2002) PAUP*-phylogenetic analysis using parsimony ( ${ }^{*}$ and other methods), version 4.0b10. Sinauer Associates, Sunderland, MA

Teske PR, Wooldridge TH (2003) What limits the distribution of subtidal macrobenthos in permanently open and temporarily open/closed South African estuaries? Salinity vs. sediment particle size. Estuar Coast Shelf Sci 57:225-238

Teske PR, Wooldridge TH (2004) Affinities of some common macroinvertebrates to salinity and sediment type: empirical data from Eastern Cape estuaries, South Africa. Afr Zool 39:183-192

Teske PR, Cherry MI, Matthee CA (2003) Population genetics of the endangered Knysna seahorse, Hippocampus capensis. Mol Ecol 12:1703-1715

Teske PR, Hamilton H, Palsbøll PJ, Choo CK and 6 others (2005) Molecular evidence for long-distance colonization in an Indo-Pacific seahorse lineage. Mar Ecol Prog Ser 286:249-260

Thiel M (2003) Rafting of benthic macrofauna: important factors determining the temporal succession of the assemblage on detached macroalgae. Hydrobiologia 503:49-57

Todd CD, Lambert WJ, Thorpe JP (1998) The genetic structure of intertidal populations of two species of nudibranch molluscs with planktotropic and pelagic lecithotrophic larval stages: Are pelagic larvae 'for' dispersal? J Exp Mar Biol Ecol 228:1-28

Tolley KA, Groeneveld, J, Gopal K, Matthee CA (2005) Mitochondrial DNA panmixia in spiny lobster Palinurus gilchristi suggests a population expansion. Mar Ecol Prog Ser 297:225-231

Wallace JH, van der Elst RP (1975) The estuarine fishes of the east coast of South Africa. IV. Occurrence of juveniles in estuaries. V. Ecology, estuarine dependence and status. Oceanographic Research Institute, Investigational Report No. 42. Durban, South Africa

Walsh PS, Metzger DA, Higuchi R (1991) Chelex 100 as a medium for simple extraction of DNA for PCR-based typing from forensic material. Biotechniques 10:506-513

Waters JM, Roy MS (2003) Marine biogeography of southern Australia: phylogeographical structure in a temperate seastar. J Biogeogr 30:1787-1796

Waters JM, King TM, O'Loughlin PM, Spencer HG (2005) Phylogeographical disjunction in abundant high-dispersal littoral gastropods. Mol Ecol 14:2789-2802

Wheeler WC (1990) Nucleid acid sequence phylogeny and random outgroups. Cladistics 6:363-367

Wooldridge TH (1994) The effect of periodic inlet closure on recruitment in the estuarine mudprawn, Upogebia africana. In: Dyer KR, Orth RJ (eds) Changes in fluxes in estuaries: implications from science to management. Olsen \& Olsen, Fredensborg, p 329-333

Wooldridge TH, Loubser H (1996) Larval release rhythms and tidal exchange in the estuarine mudprawn, Upogebia africana. Hydrobiologia 337:113-121 